G. Stankevych ${ }^{1}$, Doctor of Technical Sciences, Professor, E-mail: georgii.stn@gmail.com https://orcid.org/0000-0002-0583-8174, ResearcherID: F-8557-2016

Scopus Author ID: 56184710800

A. Kats ${ }^{1}$, PhD Tech. Science, Associate Professor, E-mail: anfisakats20@gmail.com https://orcid.org/0000-0003-4820-7636, ResearcherID: F-8743-2016

O. Bondar ${ }^{2}$, Deputy Director, E-mail: BondarO@ulf.com.ua

${ }^{I}$ Department of grain storage technology, Odessa National Academy of Food Technologies, 112, Kanatna Str., 65039, Odessa, Ukraine

${ }^{2}$ LLC “Agricultural Enterprise "Vesna 21”, bldg. 1, str. Verbetske highway, v. Huments, Kamianets-Podilskyi district, Khmelnytsky region, 32325, Ukraine

\title{
RESEARCH OF THE EFFICIENCY OF THE GRAIN RECEPTION LINE OPERATION FROM AUTO TRANSPORT AT THE PROCUREMENT PRODUCTION GRAIN ELEVATOR
}

\begin{abstract}
The results of the study of the characteristics of the technological line for grain reception from auto transport at the procurement production grain elevator of LLC "Agricultural Enterprise "Vesna 21" are presented. In the process of research, the quantitative and qualitative composition, volumes and duration of the harvesting periods of early and late crops, the quantitative and qualitative composition and characteristics of auto transport delivering grain to the enterprise were determined; the most intensive supply of early and late crops, as well as the actual coefficients of daily irregularity of their supply by auto transport.

It is shown that the enterprise in 2017-2019 traditionally received such early crops as wheat of 2-6 classes and rapeseed of the highest and 1st class. Late crops were represented by corn (3rd class and non-class) and soybeans (non-standard and extruded). The volumes of harvesting of the corn and wheat (main crops)for the indicated years correlated, respectively (\%) 49.2:41.2; 60.1: 24.9 and 66.1:17.1, which indicates a tendency for a significant increase in the supply of late crops, especially corn grain. The ratio between early and late crops for 2017-2019 was 45:55, 24:76 and 20:80, respectively (\%).

The monthly grain flow to the grain elevator was rather irregular. Most of the grain was received from July to December, when the periods of harvesting of early and late crops coincide, and especially in the autumn months, in September, October and November, up to $32.9 \%$, less - in the off-season from January to June, to $12.3 \%$. All the same, a lot of grain in percentage terms was received in November 2017 and October 2018 - $32.9 \%$ each.

An analysis of the quantitative and qualitative composition of cars that delivered grain to the procurement and production elevator in 2017-2019 showed that the carrying capacity of the vehicles ranged from 3 ... 51 tons. In 2017, 80.9\% of all grain received by the enterprise was delivered by 2771 vehicles (cars) with a carrying capacity of $20 \ldots 40$ tons, which amounted to $82.4 \%$ of their annual quantity. In 2018, these indicators were as follows $-87.2 \%$ of grain was delivered by $84.5 \%$ of vehicles of the same carrying capacity, and in 2019 - $93.4 \%$ of grain was delivered by $93.0 \%$ of the same vehicles. In the years studied, there was a tendency to an increase in the share of more heavy-duty vehicles $(35 \ldots 40 \mathrm{t})$. However, the number of vehicles with a carrying capacity of more than 40 tons, delivering significant volumes of grain, has significantly decreased, which is associated with the legislative limitation of the vehicles weight. The optimal carrying capacity in terms of the ratio of the mass of the delivered grain: the number of vehicles, taking into account legal restrictions, can be recommended $35 . . .40$ tons.

The main characteristics of the reception of an early and late crops at the procurement and production elevator, respectively, for 2017-2018 were the following values: the duration of the arrival of early crops, days - 126, 119 and 97, late - 142, 145 and 240; harvesting period of early crops, days - 73, 88 and 68, late crops - 86, 78 and 57; the most intensive supply of early crops, t/day -8378, 596 and 1428, late crops 1966, 1576 and 1909; actual coefficients of grain reception irregularity by auto transport of early crops - 6.3; 2.2 and 3.6, late - 2.5, 2.4 and 2.9, which exceeds the standard values of 1.6 and should be taken into account when improving the operation of the grain reception line.
\end{abstract}

Key words: procurement and production elevator, grain and oilseeds, grain reception line by auto transport (vehicles), coefficients of irregularity.

\section{The formulation of the problem}

The grain sector of Ukraine is a strategic sector of the state's economy. Ukraine occupies a leading position among the world's producers and exporters of the grain crops. An important component of the production, procurement, processing and grain's export is the logistics of its storage and transportation. According to experts, by 2022 the volume of grain production in Ukraine will grow to 100 million tons, and exports will reach 70 million tons [1]. The infrastructure supporting the production, processing, storage, processing and export of grain is quite complex. It includes two large components - a logistics and transport structure and the grain storage system. The task of the first of them is usually the grain delivery from producers to grain-receiving enterprises, procurement or procurement-production elevators for processing grain to the required conditions, storage and subsequent transfer for further use.

The main transport operation at the procurement elevators is the grain reception from the auto transport. It depends on the correct organization of this operation whether enterprises will be able to receive, place and 
process all grain of different quality and purpose, coming from producers, within a specified timeframe, with minimal losses and downtime for the auto transport [2].

As noted by foreign researchers, over the past two decades, the volume of transported grain has increased by almost $70 \%$. In particular, the share of the auto transport of grain has increased significantly, since auto transport usually has the advantage of grain delivering over shorter distances. In addition, it has great flexibility with respect to when, where and how much grain is delivered [3].

According to the State Statistics Service of Ukraine, in 2019, the volume of grain crops transportation by auto transport increased by $16.1 \%$ - to 22.4 million tons, excluding the activities of individuals. According to the company Pro-Consulting, which conducts marketing research of the markets, the volume of transportation by auto transport is $1.5 \ldots 2.0$ times higher and can range from 33 million to 40 million tons [4].

Successful grain reception from auto transport depends on the composition, quantity and performance of equipment and devices that must correspond to the nature of the receipt from auto transport: its type and carrying capacity, the number, volume and quality of grain lots of various crops, which are delivered to the grain elevator.

Over the past decades, the dynamics of grain supply to all elevators has changed significantly. Currently, grain producers are in no hurry to hand over grain to grain-receiving enterprises and procurement elevators, placing it in their own storages for the temporary storage, since this saves on transport costs, on payment for grain processing and storage services of an elevator and makes it possible to sell grain later with higher purchasing prices than during the harvest season.

At the same time, many production elevators begin to engage in procurement activities and, on the contrary, procurement elevators are expanding their activities by completing the construction of production buildings for processing grain into various products. With such an expansion of enterprises, certain logistical and transport problems often arise associated with the coordination of auto transport flows with the operation of grain receiving lines at elevators. This, in fact, prompted research into the operation of lines for receiving grain from vehicles at a procurement elevator, which acquired procurement and production functions.

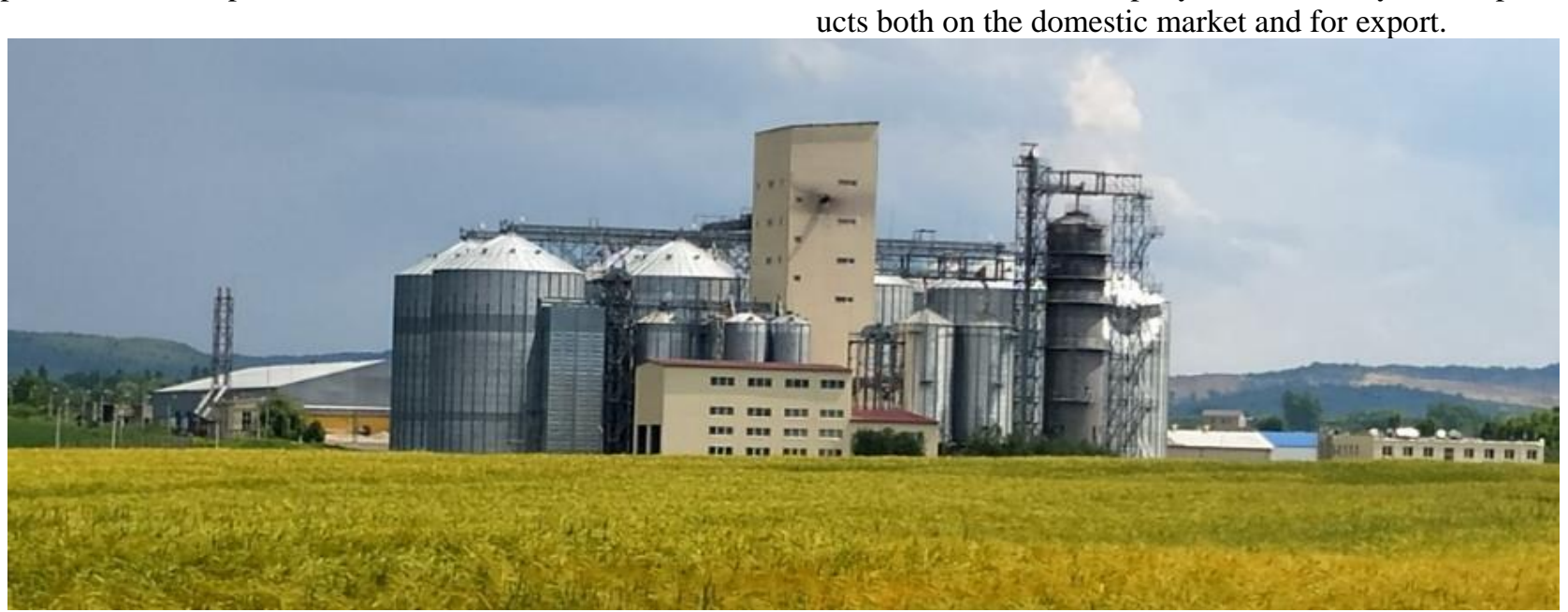

LLC “Agricultural Enterprise "Vesna 21"
The purpose and objectives of the study

The purpose of the study was to study the characteristics of a technological line for receiving grain by auto transport at a procurement and production elevator, which will increase the efficiency of grain procurement.

To achieve this goal, you need to solve the following tasks:

- to determine the quantitative and qualitative composition, volumes and duration of harvesting periods of early and late crops at the enterprise;

- to determine the quantitative and qualitative composition and characteristics of road transport delivering grain to the enterprise;

- to determine the maximum and average daily supply of early and late crops, as well as the actual coefficients of daily irregularity of their supply by auto transport.

\section{Object and subject of research}

The object of the research was the technology of grain receiving from auto transport at the procurement and production elevator; the subject of research was cereals, legumes and oilseeds, a receiving grain line from auto transport, as well as data on daily reception operations of LLC "Agricultural Enterprise "Vesna 21" (form No. 28) for three calendar years - from January 1, 2017 to December 31 Dec 2019.

Limited Liability Company "Agricultural Enterprise "Vesna 21" is located in the Khmelnytsky region. The procurement elevator was built in 2011-2012. The grain storage facilities consist of ten flat-bottomed silos with a total capacity of 55 thousand tons of grain; there are 2 grain dryers with a total capacity of up to $140 \mathrm{t} / \mathrm{h}$ and two grain cleaning machines. The line for receiving grain at the elevator includes an autoloader of the UARG-16 brand for two passages, the transport equipment has a capacity of up to $120 \mathrm{t} / \mathrm{h}$.

At first, the elevator was operated as a procurement (linear), and after the construction and commissioning of a feed mill on the territory of the enterprise in 2015, the elevator changed to a procurement-production type, with the subsequent transfer of grain to production. However, due to the large capacities for storing grain, the possibility of its completion, shipment to road and rail transport, the elevator is now partially used as a procurement one. The company has the ability to sell products both on the domestic market and for export. 

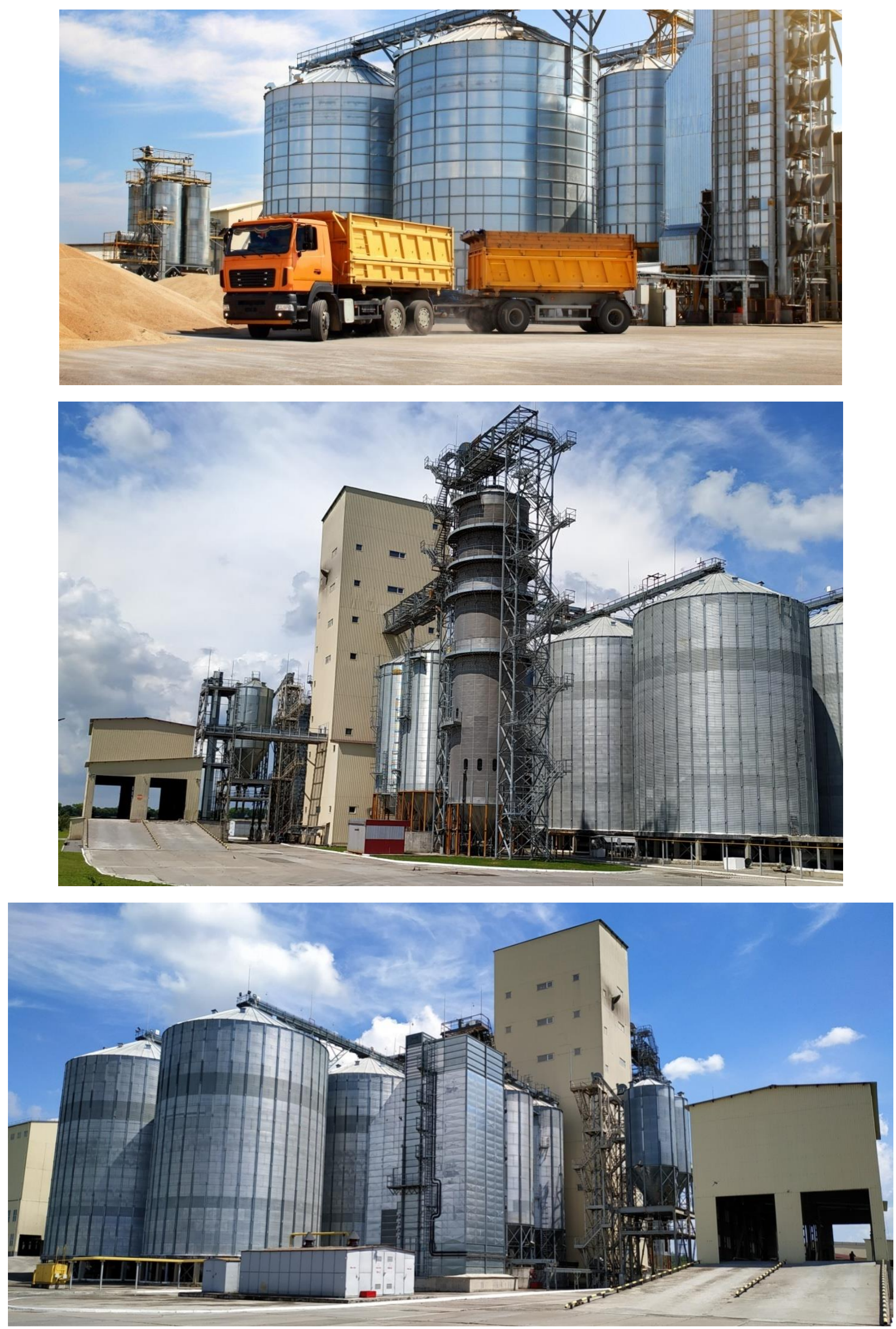

LLC "Agricultural Enterprise "Vesna 21" 


\section{Research methodology}

To determine the regularities of the quantitative and qualitative of grain supply to the procurement and production elevator by auto transport, we used the data of Form No. 28 on the amount of grain transported by vehicles daily for 2017-2019. Summary results were entered into tables for each year of grain supply. Further analysis was carried out using histograms and graphs, it was done on the basis of the specified statistical data of the enterprise, and it has given the visual representation of the patterns and characteristics of grain supply. During the research, we used the guidelines developed at the Department of grain storage technology [5].

The quantitative and qualitative composition, volumes and duration of the annual harvesting periods (the most intensive supply) of early and late crops at the enterprise were carried out according to the logs of the daily intake of cereals, legumes and oilseeds (form No. 28 ), for each year their volumes and ratio were determined for individual crops. The duration of the periods of the most intensive intake of early and late crops was determined according to the generally accepted method described in the scientific and methodological literature $[5,6]$, by constructing and analyzing the integral curves of the intake of these crops. In more detail, the essence of the graphical definition of harvesting periods and volumes of grain reception for these periods is discussed further in the research results.

Since harvesting and production elevators are characterized by the supply of early and late crops not only during the harvesting period (early crops, as a rule, in June-July, late crops in September-November), but practically throughout the year, in our studies the period of harvesting should be understood as the period of the most intensive supply of these crops to the enterprise.

To study the qualitative and quantitative composition of vehicles (cars) delivering grain to the enterprise, we have analyzed the vehicles that delivered grain to the enterprise in 2017-2019, established the range of their carrying capacity, which was divided into classes with an interval of 5 tons. Further, in each year, the numbers of vehicles of a certain class of a carrying capacity, the amount of grain delivered by them, as well as the weighted average carrying capacity were determined.

Determination of the irregularity coefficients of the daily grain intake $K_{\text {daily }}$ to the enterprise by auto transport was carried out in the following sequence $[5,6]$.

The average daily grain supply for a certain year was calculated using the formulas:

$$
A_{\text {ever.daily }}=A_{\text {total.ann }} / P_{\mathrm{d}},
$$

where $A_{\text {ever.daily }}$ - average daily grain supply, t/month, t/day;

$A_{\text {total.ann }}$ - total annual grain supply, t;

$P_{\mathrm{d}}$ - the number of days of grain supply to the enterprise in a particular year, days.

Further, from the total annual period of the grain supply, we have selected three months of the most intense (maximum) supply of early and late crops. In each of these months, three days of maximum grain supply were also chosen. Based on the data obtained, the maximum daily mean value of the early and late crops supply for each year was calculated using the formulas:

$$
A_{\text {aver.daily }}^{3 \text { max }}=A_{3 \text { daily }} / n,
$$

where $A_{\text {aver.daily }}^{3 \text { max }}$ - maximum average daily supply of early and late crops, t/day;

$A_{3 \text { daily }}$ - the amount of early or late crops, for 3 days of its supply, t/day;

$n$ - the number of days of maximum intake of early or late crops (respectively, $\mathrm{n}=3$ days).

The coefficients of daily irregularity of grain supply separately for early and late crops were determined by the formula:

$$
K_{\text {daily }}=A_{\text {aver.daily }}^{3 \max } / A_{\text {aver.daily }},
$$

where $A_{\text {aver.daily }}$ - average daily income of early and late crops for a specific year, $t /$ day.

\section{Research results}

We processed the initial data from the enterprise on the supply of legumes and oilseeds by auto transport for three years - for the period from 01/01/2017 to $12 / 31 / 2019$.

The studied enterprise traditionally received such early crops as wheat of 2-6 classes and rapeseed of the highest and 1st class. Late crops are represented by corn (3rd class and non-class) and soybeans (nonstandard and extruded).

At the first stage, the quantitative and qualitative spectrum of crops (Table 1) supplied to the enterprise was investigated. It can be seen that over three years, from 2017 to 2019, most of all corn grains (3 class) were received, most of all in 2019, namely more than $66 \%$ of the total volume of grain received for the specified year. The gross harvest of corn in 2019 amounted to 35.2 million tons from 4.9 million hectares with a yield of $71.4 \mathrm{~kg} / \mathrm{ha}$. In 2018 and 2017, the largest share of grain was also corn of the 3 class, it was received $59.39 \%$ and $48.36 \%$, respectively. This is due to the fact that the enterprise belongs to the procurement and production enterprises that receive grain, including and for a feed mill.

Table 1 - Reception of cereals, legumes and oilseeds to the enterprise in 2017-2019 (\%)

\begin{tabular}{||l||c||c||c||}
\hline \multicolumn{1}{|c||}{ Crop } & 2017 & 2018 & 2019 \\
\hline \hline Corn 3 class & 48.36 & 59.39 & 66.14 \\
\hline \hline Corn without class & 0.38 & 0.74 & - \\
\hline \hline Wheat 2 class & 0.30 & 4.86 & 0.06 \\
\hline \hline Wheat 3 class & 17.09 & 6.95 & 8.11 \\
\hline \hline Wheat 4 class & - & - & 6.19 \\
\hline \hline Wheat 5 class 6 class & 0.09 & - & - \\
\hline \hline Wheat without class & 22.63 & 8.10 & - \\
\hline \hline Wheat non standard & 0.58 & - & - \\
\hline \hline Rapeseed the highest class & 2.78 & - & - \\
\hline \hline Rapeseed 1 class & 1.05 & 4.06 & 5.33 \\
\hline \hline Soybean & 0.25 & 10.97 & - \\
\hline \hline Soybean non standard & 5.54 & - & 11.48 \\
\hline \hline Soybean extruded & 0.02 & - & - \\
\hline \hline
\end{tabular}


Among other crops in 2017, wheat took the second place in terms of supply $-17.09 \%$ of the 3 class and $22.63 \%$ of the 6 th class (total $29.72 \%$ ), other crops were in the range of $0.02 \ldots 5.54 \%$.

In 2018, other crops, except for corn, arrived in the range of $4.06 \ldots 8.10 \%$, and in 2019 - in the range of $0.06 \ldots 11.48 \%$. In the same years, the supply of soybeans has increased, including non-standard, up to $10.97 \ldots 11.48 \%$.

During studied years wheat of different classes, non-class wheat and non-standard wheat was also received unregularly - from 0.1 to $22.6 \%$, and in some years some classes (4, 5 and 6) and non-class wheat did not arrive at all (see Table 1).

Rapeseed of the highest class $(2.78 \%)$ was only in 2017, and rapeseed of the 1st class also was supplied in insignificant quantities $-1.05 \ldots .5 .33 \%$.

Such small volumes of grain supply also apply to soybeans - in 2017 it was $5.81 \%$, of which $5.54 \%$ were non-standard and $0.02 \%$ extruded. In 2018, the supply of soybeans increased to $10.97 \%$, and in 2019 it increased to almost the same limits $(11.48 \%)$ of the intake of non-standard soybeans. Note that extruded soybeans in a scanty amount $(0.02 \%)$ appeared only in 2017.

If you look at the ratio between early and late crops, then it was in the years studied, respectively (\%) $45: 55,24: 76$ and 20:80, that is, over the years, there is a noticeable tendency for a significant increase in the volume of supply of late crops.

Indicators of the monthly supply of different crops in 2017-2019 can be obtained from the histograms shown in Fig. 1.

Most of the grain was received in the autumn months, that is, in September, October and November, the least in May and June (during the off-season). All the same, a lot of grain in percentage terms was received in November 2017 and October 2018 - $32.9 \%$ each. An increased grain supply was observed from July to December, that is, when the periods of harvesting of early and late crops coincide.

Subsequently, we investigated the quantitative and qualitative characteristics of vehicles delivering grain

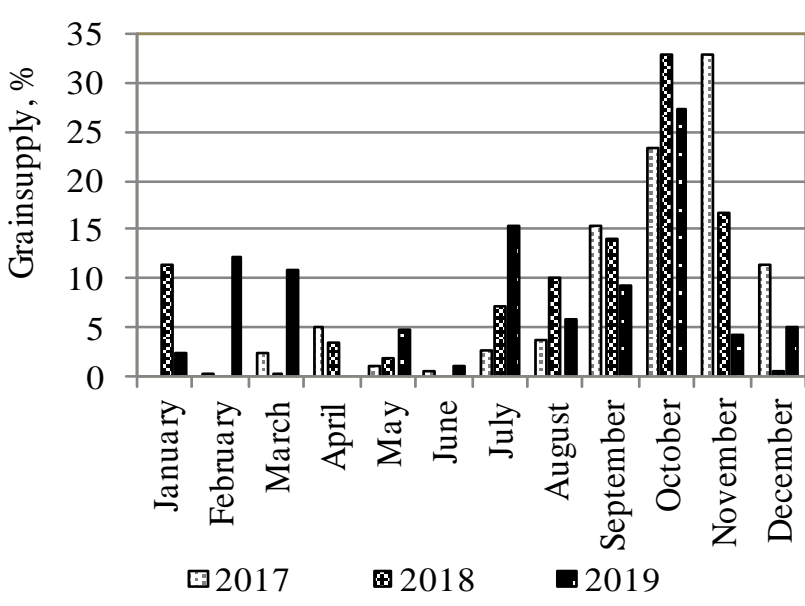

Fig. 1. Monthly shares of different crops supply to the enterprise

to the enterprise. According to the research methodology, the entire range of carrying capacity of vehicles supplied to the enterprise per year was divided into 11 classes at intervals of 5 tons. For each of the studied years, the number of cars included in each class of carrying capacity was counted and the mass of grains delivered by them was determined. Based on the data obtained, the average characteristics were calculated - the number of cars in each class and the mass of grain delivered by them in each of the studied years. The results are summarized in table. 2.

As you can see, the average carrying capacity of the cars delivering grain to the enterprise was in the range of 2.58 ...50.95 tons. The data also show that most of the vehicles, respectively, delivering the largest volumes of grain, had a carrying capacity of $20 \ldots 40$ tons. Occasionally there were also vehicles of both very small and significantly higher carrying capacity. On the basis of these data, for each class, the weighted average carrying capacity of vehicles received by the enterprise for the studied period was determined, given in the same table.2.

Data analysis in table 2 shows that in 2017 the largest grain volumes (18210.0 tons, 22422.9 tons and $28,063.4$ tons) were delivered by vehicles with a carrying capacity of $25 \ldots 30$ tons ( 665 units), 30...35 tons ( 683

Table 2 - Quantitative and qualitative composition of vehicles delivering grain to the enterprise

\begin{tabular}{|c|c|c|c|c|c|c|c|c|c|c|}
\hline \multirow{2}{*}{ Class } & \multirow{2}{*}{$\begin{array}{c}\text { Load } \\
\text { capacity, } \mathrm{t}\end{array}$} & \multicolumn{3}{|c|}{ Number of vehicles, items } & \multicolumn{3}{|c|}{ Delivered grain, $\mathrm{t}$} & \multicolumn{3}{|c|}{$\begin{array}{c}\text { The average load capacity } \\
\text { of auto transport, } t\end{array}$} \\
\hline & & 2017 & 2018 & 2019 & 2017 & 2018 & 2019 & 2017 & 2018 & 2019 \\
\hline I & less5 & 4 & 39 & 8 & 11.1 & 140.6 & 20.6 & 2.78 & 3.6 & 2.58 \\
\hline II & $5 \ldots 10$ & 12 & 139 & 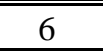 & 93.9 & 952 & 48.6 & 7.83 & 6.85 & 8.10 \\
\hline III & $10 \ldots 15$ & 24 & 17 & 20 & 307.9 & 207.1 & 245.5 & 12.83 & 12.19 & 12.28 \\
\hline 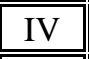 & $15 \ldots 20$ & 171 & $\begin{array}{l}42 \\
\end{array}$ & 140 & 3235 & 785.7 & 2631.8 & 18.92 & 18.71 & 18.80 \\
\hline$\overline{\mathrm{V}}$ & $20 \ldots 25$ & 677 & 531 & 1673 & 15186.1 & 11561.0 & 37808.3 & 22.43 & 21.77 & 22.60 \\
\hline VI & $25 \ldots 30$ & 665 & 464 & 557 & 18210.0 & 12822.8 & 15163.1 & 27.38 & 27.64 & 27.22 \\
\hline VII & $30 \ldots 35$ & 683 & 715 & 653 & 22422.9 & 23409.9 & 21278.6 & 32.83 & 32.74 & 32.59 \\
\hline VIII & $35 \ldots 40$ & 746 & 788 & 782 & 28063.4 & 29329.6 & 28887.7 & 37.62 & 37.22 & 36.94 \\
\hline IX & $40 \ldots 45$ & 382 & 210 & 91 & 16183.4 & 8738.2 & 3801.6 & 42.36 & 41.61 & 41.78 \\
\hline $\mathrm{X}$ & $45 \ldots 50$ & - & 11 & 7 & - & 509.5 & 324.7 & - & 46.32 & 46.39 \\
\hline 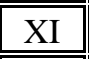 & $\begin{array}{l}50 \ldots . .55 \\
\end{array}$ & - & - & $\begin{array}{l}4 \\
\end{array}$ & - & - & $\begin{array}{l}203.8 \\
\end{array}$ & ב- & - & $\begin{array}{l}50.95 \\
\end{array}$ \\
\hline & together & 3364 & 2956 & 3941 & 103714 & 88456 & 110414 & - & - & - \\
\hline
\end{tabular}


units) and $35 \ldots 40 \mathrm{t}$ (746 pcs.). In 2018, the largest grain volumes (65562.3 tons or $74.1 \%$ ) were delivered by vehicles with a carrying capacity of $25 . .30$ tons, $30 \ldots 35$ tons and $35 \ldots 40$ tons, and in 2019 - vehicles with a carrying capacity of $20 \ldots 25$ tons, $30 \ldots 35$ tons and $35 \ldots 40$ tons, and cars with a carrying capacity of $20 . .25$ tons made up the largest annual share $(42.3 \%)$ and delivered the largest volume of grain $(34.2 \%)$.

Thus, in 2017, $80.9 \%$ of all grain received at the enterprise was delivered by 2771 auto-machines with a carrying capacity of $20 . .40$ tons, which amounted to $82.4 \%$ of their annual amount. In 2018, these indicators were as follows $-87.2 \%$ of grain was delivered by $84.5 \%$ of vehicles of the same carrying capacity, and in

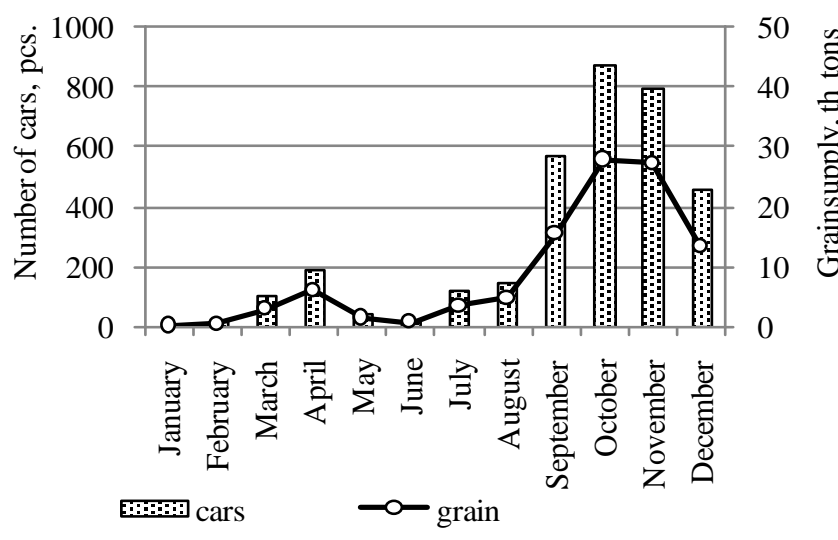

a) 2017

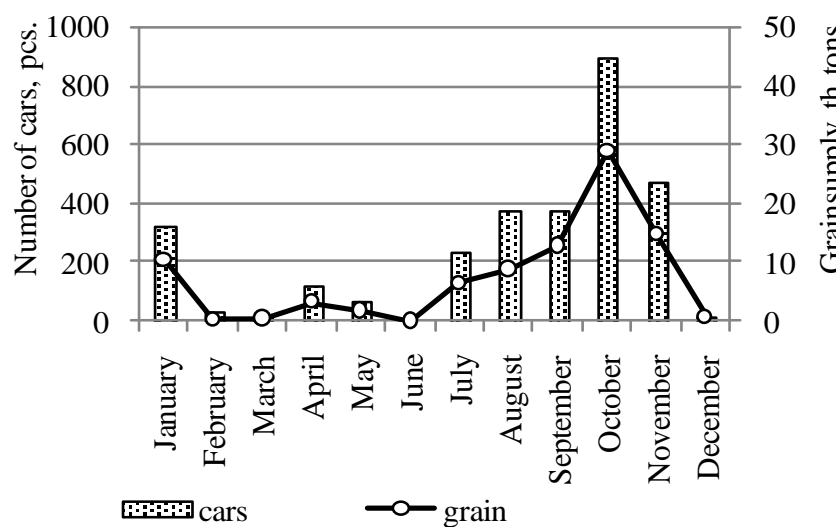

b) 2018

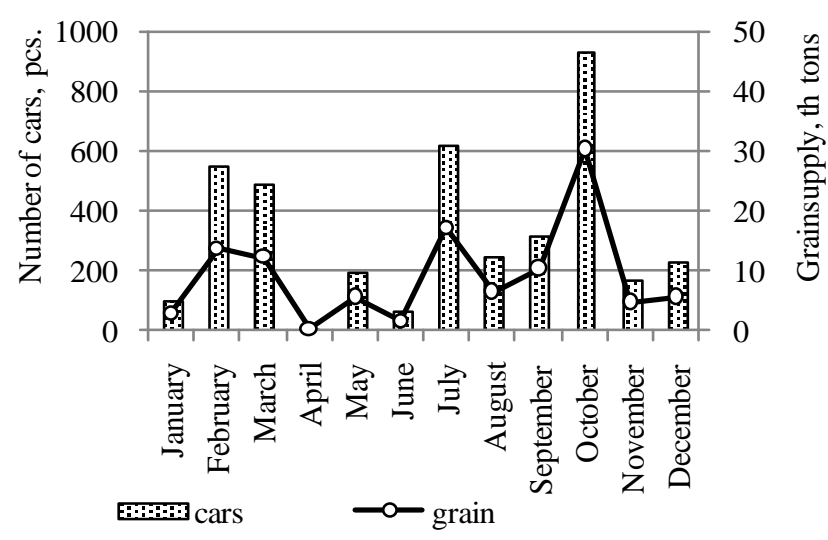

c) 2019

Fig. 2. Histograms of the monthly reception of vehicles and grain at the enterprise, which they delivered in 2017-2019
$2019-93.4 \%$ of grain was delivered by $93.0 \%$ of the same vehicles. Apparently, in the years under study, there was a tendency to an increase in the share of more heavy-duty vehicles.

It can also be seen that in 2017-2019 the number of vehicles with a carrying capacity of more than 40 tons, delivering significant volumes of grain, has significantly decreased, which is associated with the legislative limitation of the vehicle's weight. This limitation of the total weight of vehicles forces enterprises to reduce their grain load, which will lead to inefficient use of heavy vehicles when delivering grain to grain processing plants. The situation is further complicated by the fact that the production of medium-duty vehicles has not been established in Ukraine, and a duty has been imposed on imported vehicles [7].

It is known that early and late crops are delivered to grain processing plants and elevators extremelyirregularly.

Fluctuations in the monthly number of cars, as well as in the volumes of grain delivered by them, are clearly seen in the ones shown in Fig. 2 histograms of vehicle arrivals and graphs of vehicles delivered by them grain volumes in 2017-2019.

From the histograms (Fig. 2) it can be seen that in 2017-2018 the largest number of cars came as follows:2017 - in three autumn months (2254), in 2018 in August, October and November (1694) and in 2019 in February, July and October (2096). This number of vehicles delivered 85946 tons, 52320 tons and 61081 tons of grain, respectively, during the months indicated.

During all studied years the smallest number of cars were in the first half of the year, which is usually typical for procurement elevators. So, in 2017, fewer cars arrived in January, February and June, in 2018 - in February, March and June, in 2019 - in January, April and June. Considering that the investigated elevator is a procurement-production one, then in some months of the first half of the year one can observe a certain increase in the grain flow and, accordingly, in vehicles. These months in 2017 were March and April (103 and 192 vehicles), in 2018 it was January and April (324 and 124 vehicles), in 2019 - February, March and May (549, 492 and 194 vehicles). They delivered from 2827 to 13564 tons of grain in the specified months.

During the summer months (June, July, August), when the early crops begin to arrive, there is a gradual increase in the number of cars. Fig. 2 shows that already in July 625 vehicles arrived, which delivered 17176 tons of grain.

When analyzing the work or when designing grain elevators, it is necessary to have indicators on the basis of which the required performance of technological and transport equipment is calculated, as well as devices that ensure uninterrupted reception and processing of grain supply. The most important indicators for carrying out such calculations are the period of the most intensive grain supply to the enterprise (harvesting period), the amount of grain and the rate of its receipt in the specified period, characterized by the coefficients of daily irregularity of grain supply.

Today, in order to determine these data, they use the norms of technological design of grain-receiving en- 
terprises and elevators or educational literature, which currently do not correspond to the current state of technology and technology of the grain storage system $[5,6]$. Therefore, when developing projects for the construction of new or reconstruction of existing enterprises, there is a need to establish the value of the above coefficients for technological research.

Based on this, at the next stage of research, the duration of the harvesting periods of the grain supply of early and late crops, that is, the periods of their most intensive supply, was determined. For this, according to the research methodology, for each year, integral curves of the supply of separately early and late crops were constructed, according to which the duration of their intensive supply was determined by the graphical method.

Figure 3 shows a histogram characterizing the dynamics of the daily supply of late crops (class 3 corn and non-class and soybeans, including non-standard) from January 19, 2019 to December 27, 2019. Also Figure 3 shows that these crops enter the enterprise throughout the year, and not only during the harvesting period when they are harvested. From the analysis of the histograms on the volume of late crops supply, three characteristic periods can be distinguished - the minimum supply within $20 \ldots 100 \mathrm{t}$ /day (mainly June - July); average supply in the range of $100 \ldots . .500$ tons/day (first half of the year, August - September, November-December); the maximum intake is about $1500 . .2000$ tons/day (end of September - beginning of October). It is in the last period that late crops of the new harvest arrive and the highest intensity of their arrival is observed.

According to the method of graphically determining the period of the most intensive supply of late crops (harvesting period), the following was carried out. Initially, a tangent was drawn to the integral curve at the site of its steepest rise, which characterizes the highest rate of grain inflow (see thin dashed lines in Fig. 3). Vertical lines (top and bottom) were drawn from the points formed at the intersection of this tangent line with the horizontal lines of $0 \%$ and $100 \%$ grain input until the intersection with the integral curve. From the resulting points from the integral curve, horizontal lines were drawn to the left axis ("Grain supply, \%"). The distance between these horizontal lines showed the percentage of harvested late crops (in Fig. 3 this was $47 \%$ ), and the distance along the date axis between the vertical lines gave the value of the period of the most intense influx of late crops (the period of their harvesting) $P_{\mathrm{h}}=57$ days.

Similarly to the one described, the procurement periods for the reception of early and late crops for the studied period of 2017-2019 were determined.
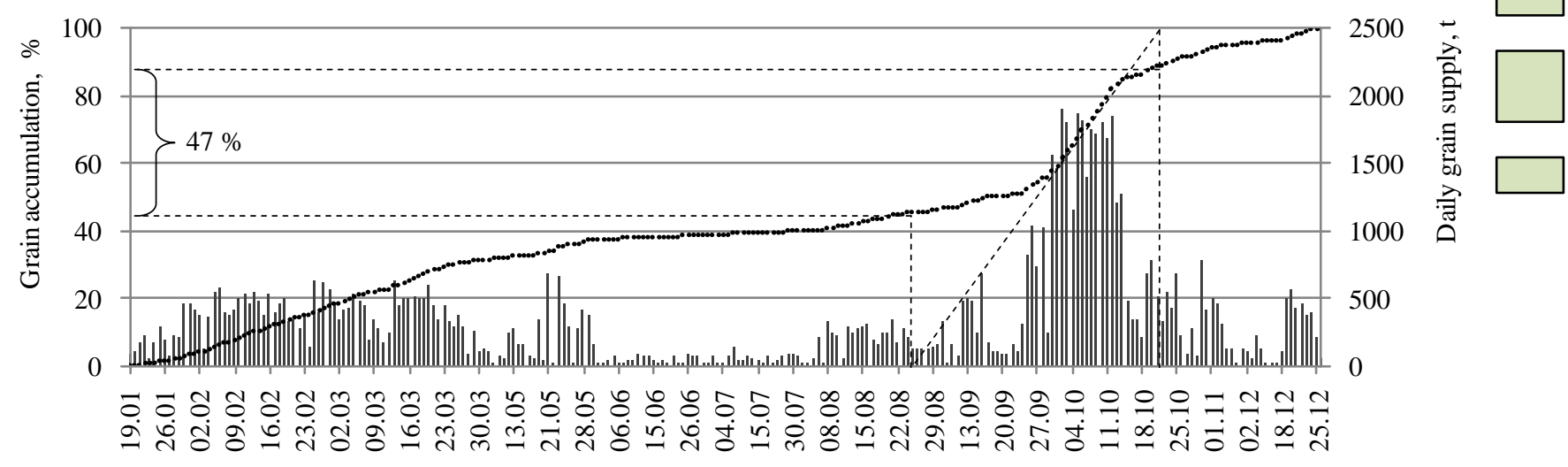

Fig. 3. Histogram of the daily income of late crops and the integrated schedule of their accumulation at the enterprise in 2019

Table 3 - Characteristics of the reception of early and late crops to the elevator

\begin{tabular}{|c|c|c|c|c|c|c|}
\hline \multirow{3}{*}{ Indicators } & \multicolumn{2}{|c|}{2017} & \multicolumn{2}{|c|}{2018} & \multicolumn{2}{|c|}{2019} \\
\hline & \multicolumn{6}{|c|}{ Crops } \\
\hline & early & late & early & late & early & late \\
\hline Duration of grain reception by road per year, days & 126 & 142 & 119 & 145 & 97 & 240 \\
\hline Estimated procurement period, days & 73 & 86 & 88 & 78 & 68 & 57 \\
\hline The volume of grain reception in the harvesting period, $\%$ & 88 & 83 & 81 & 78 & 84 & 47 \\
\hline \multicolumn{7}{|l|}{ Daily grain reception, $\mathrm{t} / \mathrm{day}$} \\
\hline- maximum & 8378 & 1966 & 596 & 1576 & 1428 & 1909 \\
\hline - for 3 days of maximum reception & 19261 & 5458 & 1682 & 4440 & 3581 & 5628 \\
\hline - average for 3 days of maximum income & 6420 & 1820 & 561 & 1480 & 1194 & 1876 \\
\hline - average daily for the harvesting period & 622 & 716 & 251 & 617 & 328 & 655 \\
\hline Coefficients of daily irregularity of grain supply & 6.3 & 2.5 & 2.2 & 2.4 & 3.6 & 2.9 \\
\hline Normative coefficients of daily irregularity [8] & \multicolumn{6}{|c|}{1.6} \\
\hline The total volume of grain receipts by auto transport per year, tons & \multicolumn{2}{|c|}{103714} & \multicolumn{2}{|c|}{88456} & \multicolumn{2}{|c|}{110414} \\
\hline
\end{tabular}


Analysis of the obtained data on the annual and daily grain reception in 2017-2019 made it possible to determine the actual coefficients of the daily irregularity of grain flow by auto transport to the elevator (according to the research methodology described above). The obtained calculation results are presented in table 3 .

From the above research results, it can be seen that the actual values of the harvesting periods of early and late crops and the coefficients of daily irregularity of grain reception by auto transport, compared with the normative ones, significantly exceed the normative ones, especially for early crops. This must be taken into account when further improving the operation of grain reception lines by auto transport.

\section{Conclusions}

1. The studied enterprise in 2017-2019 traditionally received such early crops as wheat of 2-6 classes and rape of the highest class and 1st class. Late crops were represented by corn (3rd class and non-class) and soybeans (non-standard and extruded). The volumes of harvesting of the main crops of corn and wheat for the indicated years correlated, respectively (\%) 49.2: 41.2; 60.1: 24.9 and 66.1: 17.1, which indicates a tendency for a significant increase in the supply of late crops, especially corn grain. The ratio between early and late crops for 2017-2019 was 45:55, 24:76 and 20:80, respectively (\%).

2. The monthly grain flow to the elevator was rather uneven. Most of the grain was received from July to December, when the periods of harvesting of early and late crops coincide, and especially in the autumn months, in September, October and November, up to $32.9 \%$, the least of all was during the off-season from January to June, up to $12.3 \%$. All the same, a lot of grain in percentage terms was received in November 2017 and October $2018-32.9 \%$ each.

3. Analysis of the quantitative and qualitative composition of vehicles that delivered grain to the pro- curement and production elevator in 2017-2019 showed that the carrying capacity of auto transport ranged from 3 ...51 tons. In $201780.9 \%$ of all grain received by the enterprise was delivered by 2771 vehicles with a carrying capacity of $20 \ldots .40$ tons, which amounted to $82.4 \%$ of their annual quantity. In 2018, these indicators were as follows $-87.2 \%$ of grain was delivered by $84.5 \%$ of vehicles of the same carrying capacity, and in $2019-$ $93.4 \%$ of grain was delivered by $93.0 \%$ of the same vehicles. In the years studied, there was a tendency to an increase in the share of more heavy-duty vehicles $(35 \ldots$ $40 \mathrm{t}$ ). However, the number of vehicles with a carrying capacity of more than 40 tons, delivering significant volumes of grain, has significantly decreased, which is associated with the legislative limitation of the weight of vehicles.

The optimal carrying capacity in terms of the ratio "weight of grain delivered: number of vehicles", taking into account legal restrictions, can be recommended $35 . . .40$ tons

4. The main characteristics of the grain supply of early and late crops to the procurement and production elevator, respectively, for 2017-2018 were the following values:

- the duration of the intake of early crops, days $-126,119$ and 97, late crops, - 142, 145 and 240;

- the harvesting period of early crops, days -73 , 88 and 68, late crops $-86,78$ and 57.

- the most intensive intake of early crops, t/day - 8378, 596 and 1428, late crops 1966, 1576 and 1909;

- actual coefficients of unevenness of grain flow by auto transport of early crops $-6.3 ; 2.2$ and 3.6 , late crops- 2.5, 2.4 and 2.9, which exceeds the standard values of 1.6, especially for early crops, and should be taken into account when further improving the operation of the grain reception line at the enterprise.

\section{REFERENCES}

1. U nas 52 miliony: shcho ochikuvatyme zernovu torhivliu Ukrainy v 2019 rotsi. / URL : http://uga.ua/ru/news/u-nas52-milliona-chto-ozhidat-zernovuyu-torgovlyu-ukrainy-v-2019-godu/(data zvernennia: 8.09.2020).

2. Voblykov E.M. Zernokhranylyshcha y tekhnolohyy elevatornoi promyshlennosty: ucheb. posobye. SPb.: Lan, 2005. 208 s.

6. 3-Grain Transport: Modal Trends and Infrastructure Implications. URL : https://nationalaglawcenter.org/wpcontent/uploads/assets/crs/RL32720.pdf. (дата звернення: 8.09.2020).

3. Kotenko V.I. Osoblyvosti formuvannia popytu u modeliuvanni lantsiuhiv postavok zernovykh kultur. // Suchasni tekhnolohii v mashynobuduvannia ta transporti. 2020, № 2 (15). S. 35-40.

4. Strakhova T.V., Borta A.V., Stankevych H.M. Metodychni vkazivky do vykonannia laboratornykh robit z kursu «Naukovo-doslidna robota studentiv» na pidpryiemstvakh elevatornoi promyslovosti: zi spets. 181 «Khar-chovi tekhnolohii», haluzi znan 18 "Vyrobnytstvo ta tekhnolohii», stupin «bakalavr» den. ta zaoch. form navchannia / Vidp. za vyp. H.M. Stankevych; Kaf. tekhnolohii zberihannia zerna. Odesa: ONAKhT, 2019. 50 s.

5. Anisimova L.V., Polzunova I.I. Proektirovanie elevatorov: Uchebnoe posobie. Barnaul: Izd-vo AltGTU, 2004.167 s.

6. Ne bilshe 40: yak vplyne na ahrariiv obmezhennia vahy avtotransportu. URL: https://agravery.com/uk/posts/show/ne-bilse-40-ak-vpline-na-agrariiv-obmezenna-vagi-avtotransportu (data zvernennia: 8.09.2020).

7. Vidomchi normy tekhnolohichnoho proektuvannia khlibopryimalnykh pidpryiemstv ta elevatoriv VNTP - OHIP-4628-96. Kharkiv, 1995. 
Г. Станкевич ${ }^{1}$, д-р техн. наук, професор, E-mail: georgii.stn@ gmail.com

А. Кац ${ }^{1}$, канд. техн. наук, доцент, E-mail: anfisakats20@gmail.com

O.О. Бондар ${ }^{2}$, заст. директора, E-mail: BondarO@ulf.com.ua ${ }^{1}$ Одеська начіональна академія харчових технологій, вул. Канатна, 112, Одеса, 65039, Україна ${ }^{2}$ ТОВ «Сільськогосподарське підприємство «Весна 21», буд. 1, вул. Вербецьке шосе, с. Гумениі, Кам'янеиь-Подільський р-н, Хмельнищька обл., 32325, Україна

\title{
ДОСЛІДЖЕННЯ ЕФЕКТИВНОСТІ РОБОТИ ЛІНІЇ ПРИЙМАННЯ ЗЕРНА 3 АВТОТРАНСПОРТУ НА ЗАГОТІВЕЛЬНО-ВИРОБНИЧОМУ ЕЛЕВАТОРІ
}

\begin{abstract}
Анотація
Наведено результати дослідження характеристик технологічної лінії приймання зерна з автотранспорту на заготівельно-виробничому елеваторі ТОВ «Сільськогосподарське підприємство «Весна 21». У прочесі досліджень визначено кількісно-якісний склад, обсяги та тривалість періодів заготівель ранніх і пізніх культур, кількісно-якісний склад та характеристики автомобільного транспорту, щзо доставляє зерно на підприємство; максимально інтенсивне надходження ранніх і пізніх культур, а також фактичні коефіцієнти добової нерівномірності їх надходження автомобільним транспортом. Показано, щзо підприємство у 2017-2019 рр. традиційно надходили такі ранні культури, як пшениия 2-6 класів і ріпак вищого та 1-го класу. Пізні культури були представлені кукурудзою (3 клас і некласна) та соєю (нестандартна і екструдована). Обсяги заготівель основних культур кукурудзи та пшениці за вказаними роками співвідносились відповідно як (\%) 49,2:41,2; 60,1:24,9 та 66,1:17,1, щзо свідчить про тенденцією суттєвого збільшення обсягів надходження пізніх культур, особливо зерна кукурудзи. Співвідношення між ранніми та пізніми культурами за 2017-2019 роками склало відповідно (\%)
\end{abstract} 45:55, 24:76 ma 20:80.

Помісячне надходження зерна на елеватор було досить нерівномірним. Більше всього зерна надходило з липня по грудень, коли збігаються періоди заготівель ранніх та пізніх культур, і особливо в осінні місяиі, у вересні, жовтні та листопадi, до 32,9\%, найменше - у період міжсезоння з січня по червень, до 12,3\%. Однаково багато зерна у відсотковому відношенні надійшло у листопаді 2017 р. та жовтні 2018 р. — по 32,9\%.

Аналіз кількісно-якісного складу автомашин, щзо доставляли зерно на заготівельно-виробничий елеватор у 20172019 рр. показав, щзо вантажопідйомність автомашин коливалась в межах 3 ...51 тонн. У 2017 р. 80,9\% всього зерна, щио надійшло на підприємство, було доставлено 2771 автомашинами вантажопідйомністю $20 . . .40 \mathrm{~m}$, які склали 82,4 \% від їх річної кількості. У 2018 р. иі показники були такими - 87,2 \% зерна доставили 84,5\% автомашин тієї ж вантажопідйомності, а у 2019 р. - 93,4\% зерна було доставлено 93,0 \% таких же автомашин. У досліджені роки спостерігалась тенденція збільшення частки більш вантажсоідйомних автомобілів $(35 \ldots 40 \mathrm{~m})$. Однак, кількість автомобілів вантажопідйомністю понад $40 \mathrm{~m}$, які доставляли значні обсяги зерна, суттєво зменшилась, що пов 'язане з законодавчим обмеження ваги автотранспорту. Оптимальною вантажопідйомністю за співвідношенням «маса доставленого зерна : кількість автомобілів» з урахуванням законодавчих обмежень, можна рекомендувати $35 . .40$ тонн.

Основні характеристики надходження зерна ранніх і пізніх культур на заготівельно-виробничий елеватор відповідно за 2017-2018 роками склали такі значення: тривалість надходження ранніх культур, діб - 126, 119 та 97, пізніх 142, 145 та 240; заготівельний період ранніх культур, доби - 73, 88 та 68, пізніх культур - 86, 78 та 57; максимально інтенсивне надходження ранніх культур, m/добу - 8378, 596 mа 1428, пізніх культур 1966, 1576 та 1909; фактичні коефіиієнти нерівномірності надходження зерна автотранспортом ранніх культур - 6,3; 2,2 та 3,6, пізніх - 2,5, 2,4 та 2,9, щуо перевищує нормативні значення 1,6 та повинно враховуватись при удосконаленні роботи лінії приймання зерна.

Ключові слова: заготівельно-виробничий елеватор, зернові та олійні культури, лінія приймання зерна автотранспортом, коефіцієнти нерівномірності.

У нас 52 мільйони: що очікуватиме зернову торгівлю України в 2019 рочі. / URL : http://uga.ua/ ru/news/u-nas-52-milliona-chto-ozhidat-zernovuyu-torgovlyu-ukrainy-v-2019-godu/ (дата звернення: 8.09.2020).

2. Вобликов Е.М. Зернохранилища и технологии элеваторной промышленности: учеб. пособие. СПб.: Лань, 2005. $208 \mathrm{c}$.

3. Grain Transport: Modal Trends and Infrastructure Implications. URL : https://nationalaglawcenter.org/wpcontent/uploads/assets/crs/RL32720.pdf. (дата звернення: 8.09.2020).

4. Котенко В.І. Особливості формування попиту у моделюванні ланцюгів поставок зернових культур. // Сучасні технології в машинобудування та транспорті. 2020, № 2 (15). С. 35-40.

5. Страхова Т.В., Борта А.В., Станкевич Г.М. Методичні вказівки до виконання лабораторних робіт з курсу «Науково-дослідна робота студентів» на підприємствах елеваторної промисловості: зі спещ. 181 «Харчові технологїі», галузі знань 18 «Виробничтво та технологіï», ступінь «бакалавр» ден. та заоч. форм навчання / Відп. за вип. Г.М. Станкевич; Каф. технологї̈ зберігання зерна. Одеса: ОНАХТ, 2019. 50 с.

6. Анисимова Л.В., Ползунова И.И. Проектирование элеваторов: Учебное пособие. Барнаул: Изд-во АлтГТУ, 2004. 167 c.

7. Не більше 40: як вилине на аграріїв обмеження ваги автотрансnорту. URL: https://agravery.com/uk/posts/show/ne-bilse-40-akvpline-na-agrariiv-obmezenna-vagi-avtotransportu (дата звернення: 8.09.2020).

8. Відомчі норми технологічного проектування хлібоприймальних підприємств та елеваторів ВНТП - ОГІП-46-28-96. Харків, 1995.

Received 18.04.2021

Reviewed 09.05.2021
Revised 22.05.2021

Approved 24.06.2021

Cite as Vancouver Citation Style

Stankevych G., Kats A., Bondar O. Research of the efficiency of the grain reception line operation from auto transport at the procurement production grain elevator. Grain Products and Mixed Fodder's, 2021; 21 (2, 82): 19-27. DOI https://doi.org/10.15673

Cite as State Standard of Ukraine 8302:2015

Research of the efficiency of the grain reception line operation from auto transport at the procurement production grain elevator / Stankevych G. et al. // Grain Products and Mixed Fodder's. 2021. Vol. 21, Issue 2 (82). P. 19-27. DOI https://doi.org/10.15673

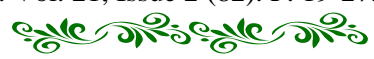

